\title{
RENESANS MYŚLENIA UTOPIJNEGO I DROGI JEGO TRANSFORMACJI W TEORII SPOLECZNEJ POCZACTKU XXI WIEKU
}

\author{
Dariusz Brzeziński \\ Instytut Filozofii i Socjologii PAN ${ }^{1}$
}

\section{/// Wprowadzenie}

Przekonanie o zmierzchu myślenia utopijnego ${ }^{2}$ było jedną z cech charakterystycznych klimatu intelektualnego końca ubiegłego wieku (zob. Jacoby 1999; Tyszka 2009: 83-103). Miało ono różnorodne źródła. Po części stanowiło konsekwencję mających wówczas miejsce przeobrażeń politycznych i społecznych, stanowiących zdaniem części intelektualistów ostateczne zwycięstwo liberalnej demokracji. Świat po „końcu historii” (Fukuyama 2009) miał być ostatecznie wolny od wojen ideologicznych, a jednocześnie gwarantować jednostkom funkcjonowanie w najdoskonalszym z moźliwych ustrojów. O rzeczywistości tej Bronisław Baczko pisał w pochodzacej z 2001 roku przedmowie do nowego wydania Świateł utopii następująco: „Społeczeństwa liberalne, giętkie i pragmatyczne, wyrzekaja się planowania swej przyszłości i w swym stosunku do czasu stawiają zdecydowanie na teraźniejszość. Byle tylko pozwolić jednostkom swobodnie działać zgodnie ze swoim interesem i przy wzajemnym poszanowaniu praw każdego [...]” (2016: 12). W wypowiedzi tej wyszczególnione zostały dwa kolejne czynniki odpowiedzialne za rozpowszechnienie się tezy o „końcu

\footnotetext{
${ }^{1}$ Instytut Filozofii i Socjologii PAN, ul. Nowy Świat 72, 00-330 Warszawa.

${ }^{2}$ W niniejszym artykule przyjmuje - za Ruth Levitas (1990) - szeroką definicję myślenia utopijnego, jako pragnienia transcendowania istniejącego stanu rzeczy, któremu może, aczkolwiek nie musi, towarzyszyć kreślenie wizji alternatywnej rzeczywistości. Tak zakreślone pole semantyczne obejmuje zarówno utopie społeczne, jak i indywidualistyczne, tak „projektanckie”, jak „ikonoklastyczne" etc.
} 
utopii”, a mianowicie załamywanie się myślenia w kategoriach prospektywistycznych na rzecz rozwoju prezentystycznej orientacji temporalnej (Bertman 1998), a także wypieranie projektów wspólnotowych przez „kulturę indywidualizmu" (Jacyno 2007). Odnosząc się do nich obu, Russel Jacoby pisał w roku 1999 w książce The End of Utopia, że fundamentalne znaczenie w polityce, filozofii i życiu społecznym odgrywało ówcześnie dowartościowanie status quo, połączone z zaabsorbowaniem prywatnymi sprawami (Jacoby 1999). Wzmiankowanym przemianom towarzyszyła jeszcze inna - być może najważniejsza - przyczyna załamania się myślenia utopijnego, mająca związek z powszechnym w owym czasie wiązaniem go z ideologiami totalitarnymi. Takie rozumienie owej kategorii obecne było zarówno w pracach wpływowych przedstawicieli myśli liberalnej (Berlin 2004, Popper 2006), jak i intelektualistów związanych z nurtem ponowoczesnym (Bauman 1998, Lyotard 1997). Rozpoznania te w znaczący sposób wpłynęły na sposób postrzegania utopii w kulturze współczesnej (Jacoby 2005).

Wzmiankowane powyżej przekształcenia można jednakowoż odczytywać z perspektywy czasu nie tyle w kategoriach zmierzchu myślenia utopijnego, ile jedynie jednej z jego form. Owa charakteryzuje się przekonaniem o potrzebie całościowej, fundamentalnej zmiany istniejącej rzeczywistości, opartej na idei zaprowadzenia niezmiennego ładu. Taki rodzaj wyobrażeń o przyszłości - wielokrotnie poddawany krytyce w myśli społecznej, humanistyce i tekstach kultury ostatnich dekad - wydaje się już nieobecny w społecznym imaginarium (zob. Berlin 2004: 18-42). Równocześnie coraz większą popularność zdobywają inne formy myślenia utopijnego, z których trzy - według mnie najważniejsze - poddam analizie w niniejszym artykule. Najpierw skoncentruję się na koncepcjach zogniskowanych na transcendowaniu istniejącej rzeczywistości, aczkolwiek niezawierających szczegółowych planów nowych struktur i instytucji. Następnie przedstawię ogólne założenia wizji określanych mianem „dionizyjskich”, które - zgodnie z cechą konstytutywną „kultury indywidualizmu” - cechują się orientacją na potrzeby jednostkowe. W końcu wskażę na to, jak w dobie „zwrotu nostalgicznego” coraz większa popularność zdobywaja idee o „retrospektywnym” charakterze. W przypadku każdego z trzech typów myślenia utopijnego wskażę na różnicę między nim i wizjami przyszłości o finalistycznym charakterze. W toku mych analiz będę starał się dowieść, że w początkach obecnego stulecia mamy de facto do czynienia z renesansem myślenia utopijnego połączonym z jego daleko posuniętą ewolucja. 


\section{/// Od utopii projektanckiej do ikonoklastycznej}

Sześć lat po wydaniu książki pod tytułem The End of Utopia Russel Jacoby opublikował monografię: Picture Imperfect: Utopian Thought for an Anti-Utopian Age (Jacoby 2005). Zanalizował w niej antyutopijne wystapienia intelektualistów drugiej połowy XX wieku, takich jak Karl Popper (1999), Hannah Arendt (2008), Jacob Talmon (1952) czy Isaiah Berlin (2004). Z jednej strony podzielił ich przekonanie, że dążenie do materializacji wizji lepszego świata może prowadzić do przemocy i terroru. Z drugiej strony dążył do wykazania, że w swych rozpoznaniach przyjmowali oni bardzo zawężona definicję utopii, redukując ją do wizji charakteryzujących się uniwersalistycznym, monolitycznym i finalistycznym charakterem przyjmowanych rozwiązań ${ }^{3}$. Wyobrażenia takie określił mianem „projektanckich” (blueprint) i umieścił na jednym krańcu kontinuum, którego drugi koniec wyznaczają jego zdaniem utopie „ikonoklastyczne” (iconoclastic). Jacoby twierdził, że gdy twórcy tych pierwszych dążą do szczegółowego nakreślenia przyszłych struktur, instytucji i kodeksów aksjonormatywnych, autorzy drugich świadomie odstępują od takich prób. Gdy w utopiach projektanckich akcent położony jest na ostateczny cel przekształceń, ikonoklastyczne zogniskowane sa jedynie na wskazywaniu kierunku owych transformacji. W konsekwencji, gdy idee doskonałego porządku implikuja podejmowanie działań o charakterze dyscyplinarnym, koncepcje obrazoburcze skłaniaja do rozwijania myślenia w kategoriach krytycznych i alternatywistycznych. Jacoby pisał przeto, że wizje ikonoklastyczne sa „,[...] «anty-utopijne» w tym sensie, że nie wiążą się z kreśleniem kształtów przyszłej rzeczywistości, zaś utopijne $z$ uwagi na wpisane w nie zaangażowanie w tworzenie innej przyszłości, opartej o idee harmonii i szczęścia" (Jacoby 2005: 85). Taka ich konstrukcja sprawia, że pozostają one niezwykle użytecznymi narzędziami we współczesnym świecie. Przyczyniają się bowiem do inicjowania zmian, nadają im kierunek, a jednocześnie pozostają wolne od niebezpieczeństw wiążących się z ukazywaniem dokładnego obrazu przyszłości.

\footnotetext{
${ }^{3}$ Warto w tym kontekście zacytować dłuższą wypowiedź Isaiaha Berlina: „Z grubsza biorąc, wszelkie utopie Zachodu zawierają te same elementy - społeczeństwo trwa w absolutnej harmonii: między jego członkami panuje pokój i wzajemna miłość, ludzie wolni są od fizycznych niebezpieczeństw, niepewności, poniżającej pracy, zazdrości i frustracji, niczego im nie brakuje, nie doświadczają niesprawiedliwości ani przemocy i żyją w ciagłej, niezmiennej jasności, w łagodnym klimacie, korzystając z dobrodziejstw nieskończenie bujnej, żyznej przyrody. Podstawową cechą większości (jeśli nie wszystkich) utopii jest fakt, iż są one statyczne. Nic się w nich nie zmienia, ponieważ osiagnęły stan idealny: nie ma potrzeby zmiany ani nowości. Nikt nie pragnie odmiany warunków, w których spełniane są wszelkie ludzkie pragnienia” (Berlin 2004: 18).
} 
Nakreślone powyżej stanowisko Russela Jacoby'ego jest reprezentatywne dla dynamicznie rozwijającego się nurtu we współczesnej myśli utopijnej. Opiera się on z jednej strony na krytyce koncepcji mających wymiar finalistyczny, czy też absolutystyczny, z drugiej zaś na unaocznianiu konieczności transcendowania istniejącej rzeczywistości w oparciu o konstrukty ufundowane na odmiennych założeniach. Obserwację tę warto zilustrować przez przywołanie wypowiedzi dwóch intelektualistów szczególnie zasłużonych w zakresie badań nad utopia. Ruth Levitas, autorka takich książek jak The Concept of Utopia (1990) i Utopia as a Method (2013) ${ }^{4}$, napisała w roku 2003, że z końcem ubiegłego wieku ,został przesunięty nacisk z treści na proces - zarówno w kwestii kształtowania wizji utopijnych, jak i sposobu pojmowania, tak współczesnych, jak i wcześniejszych wyrazów utopijnego pragnienia" (Levitas 2003: 7). Z kolei Lyman Tower Sargent, założyciel pisma „Utopian Studies”, autor i redaktor rozlicznych publikacji na temat wizji lepszego świata (Sargent 2010, Claeys, Sargent 1999)5, wypowiedział się w podobnym czasie następująco: „Zaobserwowałem, że w ostatnim czasie autorzy utopii [...] tworzą konstrukty, które są bardziej kompleksowe, wielowymiarowe, obdarzone mniejszą dozą pewności i zaprojektowane z myślą o obywatelach końca dwudziestego i początku dwudziestego pierwszego wieku” (Sargent 2005: 10-11). Godzi się przy tym zauważyć, że zarówno Levitas, jak i Sargent zdecydowanie wspieraja taki właśnie kierunek ewolucji myślenia utopijnego, uznając go za relewantny względem kondycji współczesnego świata. Przekonują jednocześnie, że jest on bardzo potrzebny w dobie rozwoju ideologii TINA (There Is No Alternative) (zob. na przykład: Levitas 2013, 2001: 25-43, Sargent 2006: 11-17, 2005: 1-14).

Refleksje na temat ewolucji współczesnej myśli utopijnej są często ufundowane - podobnie jak u Russela Jacoby'ego - na myśleniu idealnotypowym o binarnym charakterze. Jako przykład można tu przywołać podział utopii na: „totalizujące” i „ograniczone” u Jeffreya C. Alexandra (2006: 437-450), mające postać „programu” i ,impulsu” u Fredrica Jamesona (2011) czy też „osiadle” i „bez toposu” u Zygmunta Baumana (2006: 257-278). Niezależnie od różnic między rozpoznaniami podejmowanymi przez każdego

\footnotetext{
${ }^{4}$ Ruth Levitas przedstawiła w 1990 roku inkluzywną koncepcję utopii, zgodnie z którą owa „,...] wyraża i poszukuje tego, co jest pożądane, zaś pod pewnymi warunkami może zawierać także nadzieję, że pragnienie to zostanie urzeczywistnione, a nie tylko pozostanie w sferze fantazji”" (Levitas 1990: 191).

${ }^{5}$ Sargent w artykule Three Faces of Utopianism Revisited następująco zdefiniował pole prowadzonych przez siebie badań. „Utopia wyraża głęboko zakorzenione potrzeby, pragnienia i nadzieje. Dla niektórych autorów istotne jest kreślenie porządku instytucjonalnego, inni koncentrują się na ukazaniu ogólnego zestawu wartości - stanowiących jedność, uproszczonych, całościowych, odpowiednich względem ludzi i życia" (Sargent 1994: 28).
} 
z tych intelektualistów wszyscy oni zwracali uwagę na coraz bardziej dynamiczna, procesualną i wielowymiarową formę tworzonych dziś wizji lepszego świata. Alexander dowodził, że utopie oparte na nowoczesnym ,śnie o rozumie" - o holistycznym, fundacyjnym charakterze - zostały wyparte przez koncepcje o dużo skromniejszym zasięgu. Skonstatował: „Rozmontowanie kompletnego zestawu programu totalizującego (totalizing package) na części składowe stało się warunkiem przetrwania utopii jako idei. To się udało. Utopia ocalała, inspirowane nią myślenie rozkwita, a totalizujące zestawy nowoczesnych utopii należą już do przeszłości" (Alexander 2006: 441). Autor Znaczeń spotecznych zwrócił jednocześnie uwagę na to, że dzisiejsze wyobrażenia lepszego świata są ufundowane na takich wartościach, jak: wolność, pluralizm czy partycypacja. Ergo, pozostają relewantne względem heterogenicznego porządku społecznego. Fredric Jameson wskazał z kolei na to, że jakiś czas po zakończeniu zimnej wojny termin „utopia” przestał być utożsamiany z próbą całkowitego podporządkowania jednostek określonemu - w założeniu doskonałemu - planowi. „Utopijność - pisał - nie oznacza [...] już zamiłowania do specyficznej maszynerii czy planów, lecz raczej zamiłowanie do wyobrażania sobie wszelkich możliwych utopii w całej różnorodności ich form" (Jameson 2011: 258). Podkreślił ponadto, że dzięki tej przemianie postawa owa odzyskała potencjał polityczny. Bauman natomiast dowodził, że przejście od nowoczesności „stałej” do „płynnej” wiązało się z zasadniczą zmianą w zakresie formułowania wizji lepszej przyszłości. Przestały mieć one zarówno charakter „terytorialny”, jak i „finalistyczny”, a zaczęły się realizować w postaci nieskończonej wizji przekształceń, mających nierzadko ponadlokalny charakter (Bauman 2006: 257-278). Za Russelem Jacobym Bauman nazwał te koncepcje ,ikonoklastycznymi", uznając, że stanowią one znakomitą odpowiedź na wyzwania „płynnej nowoczesności” (Bauman, Rovirosa-Madrazo 2010: 91)6.

Warto w tym miejscu podkreślić, że intelektualistą szczególnie cenionym przez przedstawicieli współczesnej myśli utopijnej - w tym też tych, których rozpoznania przywołałem powyżej - jest Ernst Bloch (zob. Jacoby 2005, Levitas 2013, Jameson 2011, Sargent 2010, Bauman 2010)7. Szczególnie inspirującym dziś aspektem jego myśli jest podział na utopie

\footnotetext{
${ }^{6}$ W latach 70. XX wieku Bauman stworzył koncepcje „,aktywnej utopii”, której istota jest relatywizowanie istniejącej rzeczywistości, połączone z poszukiwaniem dla niej alternatyw i podejmowaniem starań mających na celu ich materializację (Bauman 2010). Wizja ta - w swych założeniach afinalistyczna i ,ikonoklastyczna” - stanowi antycypacje późniejszych przekształceń w myśli utopijnej (Brzeziński 2015).

7 W kwestii fundamentalnego znaczenia prac Blocha dla rozwoju współczesnego dyskursu na temat utopii zob. Levitas 1990: 83-105, Levitas 2013: 40-61, Anderson 2006: 691-710, Aidnik, Jacobsen 2017: 136-162.
} 
„konkretne” i „abstrakcyjne” (Bloch 1986). Różnicę między nimi nakreślił on następująco: „Wspólne dla utopii abstrakcyjno-społecznych jest wykraczanie poza zastane społeczeństwo, dokonujące się za pomocą obrazów i konstrukcji przeważnie tylko w głowie geniusza, bez konkretnego odniesienia intencji subiektywno-utopijnej do [...] realnej moźliwości zawartej w samej rzeczywistości. Dopiero za sprawą tego odniesienia w miejsce utopii abstrakcyjnej powstaje utopia konkretna" (Bloch 1982: 54). Eo ipso, podczas gdy „utopia konkretna” zawiera się w tworzeniu jasno zarysowanych planów, nierzadko zaopatrzonych w scenariusz wprowadzenia ich w życie, ,abstrakcyjna” zasadza się na transcendowaniu istniejącej rzeczywistości, pozbawionym drobiazgowej refleksji nad sposobem materializacji postulowanych przekształceń. Rozróżnienie to współprzyczyniło się do znaczącego poszerzenia pola semantycznego kategorii „utopii” we wspólczesnej humanistyce i myśli społecznej, a także znalazło odzwierciedlenie w zaprezentowanych powyżej podziałach binarnych. Elementy „abstrakcyjnego" podejścia do kształtowania wizji lepszej przyszłości można łatwo odnaleźć w propozycjach utopii „ikonoklastycznych”, „ograniczonych”, mających postać „impulsu” czy też pozbawionych „toposu”. Warto także podkreślić, że pisma Blocha są inspirujące dla przedstawicieli współczesnej myśli utopijnej w innym jeszcze wymiarze. Otóż intelektualista ten wyraźnie podkreślał potrzebę wyzwalania w człowieku potencjału do zmiany, a jednocześnie też otwierania go na nieskończoną wielość scenariuszy możliwej przyszłości. Posługiwał się w tym kontekście kategorią ,jeszcze-nie”, odnosząc ją do „,[...] świata, w którym możliwe są realizacje projektów i przemiany, świata, który sam jest jeszcze otwarty, niegotowy, procesualny, a przez to fragmentaryczny, jednym słowem, do świata, którego horyzont stale się poszerza" (Bloch 1982: 53). Właśnie taki obraz rzeczywistości przeciwstawiony upowszechnianemu od kilku dekad syndromowi TINA - promują wszyscy intelektualiści, których prace przywołałem w tej części artykułu.

\section{/// Od utopii apollińskiej do dionizyjskiej}

W ostatnim rozdziale Spotkań z utopia Jerzy Szacki zestawił ze sobą dwa przeciwstawne sposoby myślenia o lepszym świecie: „apolliński” i „dio-

\footnotetext{
${ }^{8}$ Godzi się przy tym podkreślić pewną - nie zawsze dostrzeganą - różnicę. Otóż zdaniem Blocha „utopia abstrakcyjna” miała pełnić przede wszystkim funkcję kompensacyjną, natomiast istotnym aspektem przywołanych tu współczesnych koncepcji jest inicjowanie zmiany w świecie zewnętrznym.
} 
nizyjski”9 (Szacki 2000: 218-219). Pierwszy z nich odniósł do koncepcji odwołujących się do trwałych, niezmiennych reguł, które miałyby stać się podstawą do budowy harmonijnego porządku społecznego. Fundacyjny, holistyczny, a zarazem porządkujący charakter tych wyobrażeń przybliża je do przywołanych w poprzedniej części tekstu utopii „projektanckich”. O koncepcjach znajdujących się na drugim krańcu kontinuum Szacki napisał: „Nowa utopia jest dionizyjska w tym sensie, że znosi wszelkie zasady, głosi triumf wolności i spontaniczności, upodabnia życie do owego święta Dionizosa, kiedy padały wszelkie bariery i nie było nakazujących oraz takich, którzy nakazów powinni słuchać” (tamże: 218). Ergo, „dionizyjskość” wiąże się z „ikonoklastycznością", ale ta jej bynajmniej nie wyczerpuje. Oznacza bowiem także dowartościowanie pragnień, emocji i afektów, które stanowia punkt odniesienia dla działań mających na celu transcendowanie istniejącej rzeczywistości. Ład normatywny - który można by utożsamić ze sfera „apollińskości” - jest w tej perspektywie postrzegany jako rzeczywistość dystopijna. Co więcej, w ramach utopii „dionizyjskich” dowartościowany zostaje indywidualizm kosztem kolektywizmu. To poszczególna jednostka jest zarówno podmiotem, jak i przedmiotem starań mających na celu ustanowienie lepszej przyszłości. Podejmowanie ich ma zaś - jak w każdej koncepcji o ,ikonoklastycznym” wymiarze - postać nieustannego ciągu różnorodnych aktywności ${ }^{10}$. Jako przykład utopii „dionizyjskich” Szacki wyszczególnił dążenia obecne w ruchach kontrkulturowych drugiej połowy XX wieku. Wskazał na praktyki: wkraczania na drogę mistycyzmu jako źródła duchowego samopoznania, kształtowania relacji międzyludzkich w oparciu o ideę braterstwa, a także rozwijania wizji powszechnego wyzwolenia $z$ wszelkich form społecznie zorganizowanej represji. W ślad za Aldona Jawłowską utopie te określił mianem ,permanentnych”, z uwagi na „,...] stała gotowość wyobraźni do rozbudowywania wizji lepszego świata we wszystkich jego możliwych wariantach" (Jawłowska 1975: 266).

We współczesnej myśli utopijnej „dionizyjskość” jest wiązana z kulturą indywidualizmu (zob. na przykład: Tyszka 2009: 94-100, Cyrzan 2004: 60-65, Bauman 2007: 131-151). Warto przy tym podkreślić zależność przyczynową między nią a przeobrażeniami mającymi miejsce w latach

\footnotetext{
${ }^{9}$ Szacki odwołał się w tym zakresie do Narodżin Tragedii Friedricha Nietzschego (Nietzsche 2012).

${ }^{10}$ Szacki przywołał kategorię utopii „,permanentnej”, wprowadzoną przez Aldonę Jawłowską. „Permanentna utopia - pisała badaczka - zakłada wielość rzeczywistości alternatywnych, które mogą być przeciwstawione odrzucanemu światu, znosi granice wyobraźni, wzbogacając wizje nowego życia o coraz nowe elementy. Nieistotna jest spójność tych wizji ani zachowanie ciagłości w ich rozbudowywaniu. Chodzi o to, aby utrzymać wyobraźnię w ruchu, zapobiec grożącej dogmatyzmem petryfikacji obrazów nowego porządku” (1975: 266).
} 
60. ubiegłego wieku. Małgorzata Jacyno pisała w tej materii następująco: „Kontrkultura i «nowa klasa średnia» przeciwstawiły ascezie, ponurej pobożności, pesymizmowi, melancholii i formalizmowi starej burżuazji nowe wartości - «cieszenie się życiem» i optymizm oraz nowe obowiązki - bycie plastycznym, kreatywnym, młodym, urodziwym i szczęśliwym. [...] Po rewolcie lat 60. dobre samopoczucie stało się «symptomem» zbawienia w zsekularyzowanym świecie" (Jacyno 2007: 9-10). Utopijność współczesnej kultury wyniosła zatem z okresu buntu zarówno określone spojrzenie na sferę aksjologii, jak i przekonanie o potrzebie wyzwolenia człowieka z ograniczeń, które odsuwały moment osiągnięcia przez niego poczucia spełnienia. W odniesieniu do pierwszej z tych kwestii warto podkreślić, że najwyższą wartością w kulturze indywidualizmu stał się dobrostan jednostki. Definiuje się go za pośrednictwem generalnych, bardzo pojemnych kategorii, które w miarę upływu czasu wypełniane są różnymi treściami. O ich wyborze decyduje sama jednostka, której aspiracje i pragnienia pozostają wciąż in statu nascendi. Z tym wiąże się druga z wyszczególnionych powyżej kwestii, to jest zmiana orientacji temporalnej w zakresie kształtowania wizji lepszej przyszłości. Otóż horyzont czasowy uległ w tym zakresie znaczącemu zawężeniu. Pragnienia nie są już odkładane ad calendas graecas; ich miejscem spełnienia jest teraźniejszość. Można zatem stwierdzić, że utopia zindywidualizowana pozostaje ,ikonoklastyczna”, procesualna i samorządna.

W bardzo ciekawym artykule poświęconym refleksji nad wzmiankowanymi tu procesami Krzysztof Tyszka stwierdził: „Wydaje się, że przejawów [...] refleksji krytycznej, a tym samym myślenia utopijnego, należy szukać w wymiarze życia jednostkowego, nie zaś społecznego. [...] Nowy człowiek i nowy świat możliwy jest tylko poprzez stworzenie warunków do nieskrępowanej ekspresji każdej jednostki, odkrycia i wyrażenia własnej prawdy i własnego wyobrażenia ideału dobrego życia" (Tyszka 2009: 9495). Za Jerzym Szackim określił on ów sposób kształtowania wyobrażeń o lepszym świecie mianem „dionizyjskiego”. Uznał, że charakteryzujące go dowartościowanie wolicjonalności i afektywności znakomicie wpisuje się w kondycję początku XXI wieku. Jakkolwiek zarówno charakter obietnic związanych z tym rodzajem myślenia utopijnego, jak i sposób ich realizacji, znacząco różnią się od wizji charakterystycznych dla czasów minionych, to pozostają one sposobem na dawanie ludziom nadziei na uczynienie ich świata lepszym. Warto w tym miejscu podkreślić, że rozwijając te refleksje, Tyszka wsparł się na rozpoznaniach Zygmunta Baumana, zogniskowanych na przemianach tożsamościowych, towarzyszących przejściu od „stałej” 
do „płynnej” nowoczesności (zob. na przykład: Bauman 2007). Chciałbym tu przywołać zwłaszcza jeden jego tekst, w którym określił on współczesny model tożsamości mianem „utopii myśliwych” (2007: 131-151). Nawiązując do swych wcześniejszych prac poświęconych kulturom „dzikim” i „ogrodniczym”" , uznał, że w odróżnieniu tak od praktyk wynikających z przywiązania do dziedzictwa przeszłości, jak i dążeń do przekształcenia rzeczywistości w zgodzie ze szczegółowo nakreślonym planem, kultura indywidualizmu wiąże poczucie spełnienia z dotrzymywaniem kroku nieustającej zmienności współczesnego świata. Stała multiplikacja możliwości otwierających się dziś przed jednostką, a także obawa przed niewykorzystaniem ich w pełni, stanowia przy tym dodatkowe czynniki dynamizujące podejmowane przez nią starania. Bauman odniósł się do tej kwestii w następujących słowach: „Marzenie o uczynieniu niepewności bardziej strawna, a szczęścia z kolei bardziej trwałym, poprzez zmianę własnego ego opartą na zmianie garderoby stanowi ową «utopię» myśliwych - «zderegulowaną», «sprywatyzowaną» i «zindywidualizowaną» wersję dawniejszych wizji dobrego społeczeństwa; społeczeństwa przyjaznego człowieczeństwu swoich członków" - napisał (2007: 147).

Trzeba jednakowoż podkreślić, że procesy związane z rozpowszechnieniem się „dionizyjskich” wizji przyszłości są bardzo różnie ewaluowane przez intelektualistów. Małgorzata Jacyno w przywołanej już książce poświęconej kulturze indywidualizmu nakreśliła dwa opozycyjne, acz krytyczne wobec niej stanowiska (Jacyno 2007: 8-9). Reprezentanci jednego z nich, związani z myśla prawicową, wiążą tę kondycję ze zrywaniem więzów wspólnotowych i chaosem aksjologicznym. Na drugim krańcu kontinuum znajdują się przedstawiciele światopoglądu lewicowego, podkreślający jej represyjny charakter, wyrażający się w wywieraniu na jednostkę ciagłej presji, by dotrzymywała tempa przekształceniom współczesnego świata. W obu tych przypadkach „dionizyjskość” postrzegana jest w kategoriach dystopijnych i nierzadko stanowi podstawę do rozwijania myśli krytycznej i alternatywistycznej. Kwestię tę dobrze ilustrują rozpoznania Marka Featherstone'a (zob. Featherstone 2007, 2009). Kilka lat temu wprowadził on pojęcie „utopii kinetycznej”12 jako powstałej w ramach neoliberalnego

\footnotetext{
${ }^{11}$ Bauman zapożyczył koncepcje podziału kultur na „dzikie” i „ogrodnicze” od Ernesta Gellnera (Gellner 1991: 65-68). Była ona bardzo ważną inspiracja jego analiz zawartych w Prawodawcach ittumaczach (Bauman 1998).

${ }^{12}$ Featherstone przeciwstawił sobie utopie „konserwatywną” i „kinetyczną". Tę pierwszą utożsamił z dążeniem do utworzenia porządku społecznego całkowicie odmiennego od istniejącego obecnie, a jednocześnie charakteryzującego się niezmiennością. Drugą charakteryzuje jego zdaniem pragnienie nieustającej zmiany. Wydaje się, że rozróżnienie to koresponduje z podziałem na utopie ,apollińskie” i „dionizyjskie”.
} 
kapitalizmu formy wyobrażeń o lepszym świecie, charakteryzującej się pełna partycypacją w kulturze konsumpcyjnej (Featherstone 2009). W jego przekonaniu wizja ta jest nie tylko dyscyplinarna, ale też „totalitarna”, jako że zawłaszcza wszelkie płaszczyzny życia społecznego. W związku z tym w znaczący sposób utrudnia rozwijanie opozycyjnych wobec niej sądów. Featherstone postawił sobie za cel, by podejmować wysiłki zmierzające do wyzwolenia z dystopijnego charakteru kondycji współczesnej. Takie samo stanowisko zajął Zygmunt Bauman, dla którego refleksja nad istotą „utopii myśliwych" była podstawą do krytyki wielu charakterystycznych dla niej procesów, a także przeciwstawienia jej wizji przyszłości opartej na budowie poczucia odpowiedzialności za dzisiejszy świat (zob. Brzeziński 2015). Rozpoznania obu intelektualistów są ciekawym przykładem zaangażowanego charakteru refleksji poświęconej wyobrażeniom lepszej przyszłości. Dowodza także ambiwalentnego statusu wszelkich wizji szczęścia, jako że ich ocena jest zawsze zapośredniczona w określonym systemie wartości. W końcu też stanowią wyraz współczesnych poszukiwań rozwiązań wykraczających poza omawianą tu opozycję: „apollińskość” - „dionizyjskość”.

\section{/// Od utopii prospektywistycznej do retrospektywnej}

Wyobrażenia utopijne można także uporządkować na kontinuum, którego jeden kraniec wyznaczałyby koncepcje ufundowane na idei powrotu do utraconego niegdyś, modelowego porządku, na drugim zaś znalazłyby się te, w przypadku których ideał lepszego świata znajduje się w - nierzadko bliżej nieokreślonej - przyszłości. Wizje należące do pierwszego typu, określane często mianem „retrospektywnych”" ${ }^{3}$, odwołują się do idei „złotego wieku”. W najszerszym zakresie jest nim szczęśliwy początek dziejów ludzkości, w węższym zaś ten okres w historii określonego narodu, kultury bądź grupy, który charakteryzował się największą miarą jej rozwoju. Z tej perspektywy późniejsze wydarzenia postrzegane są w kategoriach ciągłego regresu, zaś rozpowszechnianiu się tego przekonania towarzyszy narastanie nastrojów nostalgicznych. Owe moga - aczkolwiek nie muszą - skłaniać do podejmowania działań mających na celu przywrócenie status quo ante. Druga grupę tworzą wyobrażenia „prospektywistyczne”, budowane

\footnotetext{
${ }^{13}$ Utopię „retrospektywną” można by określić za Tadeuszem Palecznym mianem „kontrkontestacji” (Paleczny 1997: 53). Kategorię tę zastosował on na określenie sprzeciwu względem szybkości lub kierunku zmian mających miejsce w danej społeczności, połączonego z postulatem powrotu do „konserwatywnych” wartości.
} 
w oparciu o przeciwstawną orientację temporalna. W ich świetle teraźniejszość ujmowana jest jako element ciagu przeobrażeń, mających finalnie prowadzić ku zespoleniu bytu i powinności. Upowszechnienie takich utopii nastąpiło w kulturze europejskiej w dobie nowoczesności. Wówczas to kształtowała się wiara w możliwość stworzenia zupełnie nowych struktur i instytucji, w doskonały sposób odpowiadających na potrzeby człowieka. Jej pochodną były wizje ,projektanckie” lub ,apollińskie”. Dążenia takie - jak już wyżej podkreślałem - przestały w ostatnich dekadach wyznaczać horyzont myśli i oczekiwań intelektualistów ${ }^{14}$. Równolegle do tego procesu coraz większe znaczenie zdobywa obecnie utopia ,,retrospektywna”, stanowiąca pochodną, „zwrotu nostalgicznego” w kulturze współczesnej (zob. Cross 2015, Boym 2001).

W odniesieniu do obu wzmiankowanych typów wyobrażeń o lepszym świecie Jerzy Szacki napisał: „[...] utopie każdej epoki, jeśli nawet wybiegają daleko w przyszłość lub - wprost przeciwnie - szukają ideału w zamierzchłej przeszłości, noszą na sobie piętno tego czasu i miejsca, w jakich powstały. [...] Nic w tym dziwnego, utopie sa bowiem odpowiedziami nie tylko na wieczne pytania dotyczące kondycji ludzkiej, lecz również, a nawet przede wszystkim, na pytania konkretnych historycznych społeczeństw” (Szacki 2000: 50). Ergo, poszukując przyczyn współczesnego dowartościowania przeszłości, a także podejmując refleksję nad sposobem, w jaki podlega ona procesowi mitologizacji1 ${ }^{15}$, trzeba skierować uwage na własności obecnej kondycji. Szczególnym zainteresowaniem należy objąć te z nich, które postrzegane są w kategoriach braku w porównaniu z wcześniejszymi formami uspołecznienia ${ }^{16}$. Warto w tym kontekście przywołać - po pierwsze - wzmiankowane wcześniej głosy krytyczne względem utopii „dionizyjskiej”. Dotyczyły one osłabiania więzów wspólnotowych, utraty znaczenia tradycyjnych wartości, braku możliwości działania poza mecha-

\footnotetext{
${ }^{14}$ Wiara ta nie zanikła zupełnie, czego wyrazem jest między innymi myśl trashumanistyczna. „Transhumanizm - pisze Monika Bakke (2010: 339, 341) - oferuje wizję technologicznej utopii realizującej projekt samodoskonalenia się człowieka, w konsekwencji czego ludzkość może czuć się zaszczycona, będąc «pierwszym w całym znanym nam wszechświecie gatunkiem zwierzęcym, który sam stwarza warunki do powstania swojego zastępcy». [...] transhumaniści w istocie identyfikuja się z humanizmem uprawianym w duchu oświeceniowym, czyli w centrum lokują takie cechy, jak racjonalizm, samoświadomość, samokontrola oraz wiara w postęp".

${ }_{15}$ Marek Zaleski pisał w tym kontekście: „Nostalgikowi chodzi nie tyle o utracona przeszłość, ile o własne wyobrażenia na jej temat i uczucia z nimi związane” (Zaleski w: Saryusz-Wolska, Traba 2014: 276).

${ }^{16}$ Bryan Turner wyszczególnił kilkanaście lat temu następujące czynniki decydujące o zrodzeniu się odczuć nostalgicznych: poczucie historycznego upadku, przekonanie o nastaniu kryzysu aksjologicznego, wrażenie utraty możliwości nawiązywania szczerych relacji z innymi, a także pragnienie powrotu do czasów charakteryzujących się dowartościowaniem prostoty, autentyczności i spontaniczności (Turner 1987: 147-156).
} 
nizmami rynkowymi etc. ${ }^{17}$. Po drugie, poczucie braku jest dziś wypadkowa ciągłej akceleracji zmian i związanej z tym coraz większej nieprzewidywalności przyszłości (zob. Bauman 2007, Bertman 1998). Svetlana Boym pisała w tym kontekście, że: „Nostalgia pojawia się nieuchronnie jako mechanizm obronny w czasie przyśpieszenia rytmu życia i dziejowych wstrząsów" (Boym 2001: xiv). Przeszłość widziana przez jej pryzmat jawi się jako oaza stabilności i bezpieczeństwa. Po trzecie, wśród wielu innych przyczyn współczesnej tęsknoty za przeszłością warto wymienić przeświadczenie o pogłębianiu się niekorzystnych zmian, będących wynikiem rozwoju cywilizacyjnego i technologicznego. Przez wiele lat dyskurs ten rozwijał się wokół kategorii „,społeczeństwa ryzyka” (Beck 2009), jego najnowszą reprezentacja jest natomiast debata na temat antropocenu (Bińczyk 2018).

Nostalgia jest dziś jedną z najważniejszych dominant kultury zachodniej, oddziałując na podejmowane praktyki i sposoby kształtowania wizji przyszłości. W odniesieniu do pierwszej z tych płaszczyzn warto wskazać choćby na fakt coraz większej popularności, jaką cieszą się obecnie odwołania do historii w tekstach kultury, sposobach aranżacji wnętrz, trendach modowych etc. Nawiązania te moga dotyczyć zamierzchłych dziejów, jak to ma miejsce choćby w przypadku retrofutyryzmu czy steampunku (Guffey 2014: 249-266, Molenda 2016: 1-16). Rosnące tempo zmian przydaje jednak także atrakcyjności wytworom ostatnich dekad, chociażby pochodzącym z lat 90. (Połap 2016: 7-13). Nostalgia coraz częściej znajduje swoje odzwierciedlenie w kulturze konsumpcyjnej i jest przez nia poddawana petryfikacji. W konsekwencji jednak - jak dowodzi Gary Cross (2015) - historia traci swoja głębię, a jej związki z teraźniejszością stają się problematyczne ${ }^{18}$. Biorąc pod uwagę drugą z wyszczególnionych płaszczyzn, warto natomiast zauważyć, że wizje przyszłości kształtowane w oparciu o doświadczenie nostalgii stanowią swoistą koincydencję utopii retrospektywnej i prospektywistycznej. Svetlana Boym pisała: „Wyobrażenia przeszłości, ukształtowane przez potrzeby teraźniejszości, mają bezpośredni wpływ na realia życia w przyszłości. Rozważania poświęcone przyszłości sprawiają,

\footnotetext{
${ }^{17}$ Mateusz Grodecki skonstatował, że: ,„[...] historycznie wyobrażone życie społeczne utożsamiane jest z prostota, większym poziomem wspólnoty i bliskości relacji między jednostkami oraz swobodną ekspresją emocji, niepoddawaną kontroli wywodzących się z zasad rynkowych" (Grodecki 2016: 318).

${ }^{18}$ Cross wskazał na to, że proces ów zaczął się już w latach 70. ubiegłego wieku. W tej i kolejnych dekadach analizowali go między innymi Umberto Eco (1999: 11-73) i Jean Baudrillard (1998: 37-98). Już wówczas akcentowali to, że coraz częstsze odwoływanie się do czasów minionych jest procesem rewersyjnym względem postępującej akceleracji rzeczywistości. Funkcje tych działań są jednak ich zdaniem przeciwskuteczne, gdyż przeszłość zamienia się w ich wyniku w „synchroniczną sieć relacji”.
} 
że bierzemy odpowiedzialność za nostalgiczne opowieści” (Boym 2001: xvi). Eo ipso, zarówno forma, w jakiej przejawia się nostalgia, jak i charakter wyobrażeń dotyczących przyszłości, są konstruktami, pomiędzy którymi zachodzi relacja przyczynowo-skutkowa. Przekonanie o osłabieniu lub zaniku szczególnie ważnych dla danej grupy wartości, norm bądź praktyk stanowi z jednej strony podstawę rozwijania wyobrażeń o rzeczywistości, w której owe stanowiłyby znów istotny komponent. Z drugiej strony działania te wiążą się zazwyczaj z kształtowaniem apologetycznego stosunku do minionych dziejów i tworzeniem ich zniekształconego, zmitologizowanego obrazu.

Wizje retrospektywne stały się przedmiotem bardzo ciekawej analizy w ostatniej - wydanej pośmiertnie - autorskiej książce Zygmunta Baumana pod tytułem Retrotopia. Rozpoznania w niej zawarte dobrze jest ująć w perspektywie przywoływanych wcześniej refleksji tego autora dotyczących utopii zindywidualizowanej. Tak bowiem jak w przypadku tejże nastapiło przewartościowanie wielu wcześniejszych aspektów podejścia do tworzenia wizji lepszego świata, tak obecnie następuje renesans części z nich, choć nierzadko już w odmienionej formule ${ }^{19}$. Bauman pisał na ten temat następująco: „Z ruchu podwójnej negacji utopii rozumianej w tradycji More’a - odrzucenia jej, a następnie wskrzeszenia - dziś rodzą się «retrotopie»: wizje osadzone w utraconej/skradzionej/porzuconej, ale nieumarłej przeszłości, zamiast przywiązania do tego, co dopiero ma się narodzić, a więc do przyszłości jeszcze niezaistniałej” (Bauman 2018: 13). Upowszechnienie się wizji retrospektywnych jest zdaniem tego autora wynikiem kontaminacji lęku przed coraz bardziej niepewna przyszłością oraz wyzwań, jakie na każdej płaszczyźnie życia stwarza „upłynnianie” rzeczywistości (Bauman 2007). W konsekwencji punktem odniesienia dla kształtowania - tak społecznych, jak indywidualnych - nadziei staje się doświadczenie przeszłości. Wśród przykładów, którymi Bauman podpierał swą argumentację, chciałbym uwydatnić kwestię odwrotu od strategii politycznych opartych na ideach kosmopolitycznych i uniwersalistycznych, ku tendencjom partykularystycznym. Towarzyszy mu tendencja do budowania przynależności grupowej (czy też „plemiennej”), jako przeciwwagi dla narastającego indywidualizmu. Ten ostatni przybiera zaś obecnie w przekonaniu autora Ptynnej nowoczesności nowe formy, związane z pragnieniem osiągniecia wolności od wpływów, jakie na jednostkę wywiera współczesna kultura. Wszystko

${ }^{19}$ Odwołując się do filozofii Derridy, Bauman określa te próby mianem iteracji, w odróżnieniu od reiteracji (Bauman 2018: 20-21; w kwestii derridiańskiej koncepcji iteracji zob. Skrzypczak 2010: 107-124). 
to razem - choć budowane jest w oparciu o fundament utopijny - ukazywane jest przez niego w kategoriach dystopii. Nie tylko bowiem nie stanowi adekwatnej odpowiedzi na wyzwania współczesnego świata, ale je także petryfikuje i multiplikuje.

Nie tylko zdaniem Baumana, ale też wielu innych badaczy, jedną z najistotniejszych egzemplifikacji myślenia utopijnego o retrospektywnym wymiarze stanowi dziś rozwój tendencji nacjonalistycznych (Eger, Valdez 2015: 115-130, Kołodko, Koźmiński 2017: 172-188, Smolik 2015: 98-111). Nostalgia przybiera w tym przypadku postać tęsknoty za czasami, w których życie członków danej zbiorowości w dużo większym stopniu wyznaczały wartości i wierzenia uznawane za konstytutywne dla niej. Eo ipso, postawa ta konstytuuje się w kontrreakcji do tendencji kosmopolitycznych, uznawanych przez jej orędowników za destrukcyjne dla życia wspólnotowego. Thomas Hylland Eriksen pisał na ten temat, że globalizacja „,...] podsyca fundamentalizm i inne formy misyjnego uniwersalizmu, a także zaściankowej lokalności, ponieważ globalna integracja, wywołując poczucie wyobcowania, stanowi zagrożenie dla tożsamości i idei suwerenności politycznej" (Eriksen 2013: 245). Andrzej Koźmiński, który wraz z Grzegorzem Kołodką opublikował niedawno książkę (zbiór rozmów) poświęconą owej problematyce, przekonywał natomiast: „Współczesny nacjonalizm wypłynął na powierzchnię, odrodził się w wyniku kryzysu, [...] a ściślej w wyniku poczucia deprywacji, niepewności, zagrożenia odczuwanego przez klasy średnie w rozwiniętych krajach. To poczucie niepewności jest wynikiem zagrożeń, jakie niesie ze soba globalizacja, i można pogodzić się z określeniem, że jest ona bękartem neoliberalizmu, aczkolwiek ja bym raczej powiedział, że on jest ślubnym potomkiem neoliberalizmu" (Kołodko, Koźmiński 2017: 174). Odnosząc się do tych wypowiedzi, chciałbym pokusić się o antycypację, iż wzmiankowane tendencje będą się w najbliższej przyszłości nasilać. Świadczy o tym choćby rosnące poparcie dla partii głoszących poglądy o wyraźnie nacjonalistycznym charakterze, a także coraz istotniejsza rola, jaką w konstruowaniu tożsamości kulturowej odgrywa dziś poczucie identyfikacji ze wspólnotą narodową. Uważam przy tym, że rozwój utopii retrospektywnych będzie szedł w parze z dalszym upowszechnianiem się opozycyjnych ideałów utopii kosmopolitycznej (zob. Hayden, El-Ojeili 2009), zaś obie te tendencje będą się nawzajem legitymizować i wzmacniać. 


\section{/// Zakończenie}

Wbrew twierdzeniom głoszonym powszechnie w myśli społecznej i humanistyce końca XX wieku, nie nastał wówczas bynajmniej „kres utopii”. Wręcz przeciwnie, początek kolejnego stulecia to okres bardzo dynamicznego rozwoju wizji lepszego świata, a jednocześnie też znaczących przekształceń w zakresie sposobu, w jaki te są konstruowane (zob. Jacobsen, Tester 2012, Moylan, Baccolini 2007, Rüsen, Fehr, Rieger 2005). W niniejszym artykule przedstawiłem kilka dróg owych przeobrażeń, a także odniosłem się do poświęconych im teorii w myśli społecznej. Rozpoznania te pozwalają na przedstawienie kilku ogólniejszych wniosków dotyczących kondycji utopii na początku bieżącego stulecia. Po pierwsze: powszechnie krytykowane są dziś idee „projektanckie”, zakładające możliwość ustanowienia niezmiennego, doskonałego porządku. Zostały one uznane za niosące ze sobą niebezpieczeństwo totalitaryzmu i przemocy oraz całkowicie nieprzystające do współczesnego, „płynnego” świata. Po drugie, konstrukty utopijne coraz częściej przybierają obecnie postać procesualna, są wielowariantowe i zakładaja aktywistyczny udział jednostek w ich tworzeniu. W zakresie podejścia do kształtowania wizji przyszłości wiele z nich pozostaje bliżej bieguna ,ikonoklastyczności”. Po trzecie, wyobrażenia lepszego świata w XXI wieku nie dotyczą wyłącznie - a nawet przede wszystkim - wymiaru kolektywnego. Odzwierciedlają coraz częściej plany, nadzieje i pragnienia poszczególnych jednostek, zaś w ich dowartościowaniu istotny udział ma kultura indywidualizmu. Po czwarte, poza utopiami „,prospektywistycznymi”, zorientowanymi na odległą - być może nigdy nieosiągalną przyszłość, rozwijają się dziś dynamicznie wizje skupione na teraźniejszości lub przyszłości. Pokazałem na różnych przykładach, że w konstytuowaniu się tych pierwszych istotną rolę odgrywa konsumpcjonizm, te drugie są zaś owocem rozwijającego się doświadczenia nostalgii. W końcu też - po piąte - należy podkreślić, że coraz więcej badaczy wskazuje obecnie na potrzebę rozwijania myślenia utopijnego jako przeciwstawnego syndromowi There Is No Alternative. Uznawane jest ono za podstawę wszelkiej refleksji mogącej prowadzić do zmiany. W pełni słuszne są dziś zatem słowa Szackiego: „Trzeba pisać dalszy ciąg dziejów utopii. Materiałów z pewnością nie zabraknie" (Szacki 2000: 228). 
Bibliografia:

/// Aidnik M., Jacobsen M.H. 2017. Not yet: Probing the potentials and problems in the utopian understanding of Ernst Bloch and Zygmunt Bauman, [w:] Beyond Bauman. Critical engagement and creative excursions, red. M. Hviid Jacobsen, Routledge, s. 136-162.

/// Alexander J.C. 2006. Sita utopii i utopia naprany obywatelskiej, tłum. P. Sadura, [w:] Wspótczesne teorie socjologiczne, red. A. Jasińska-Kania, L.M. Nijakowski, J. Szacki i M. Ziółkowski, t. I, Scholar, s. 437-450.

/// Anderson B. 2006. 'Transcending Without Transcendence': Utopianism and an Ethos of Hope, „Antipode”, nr 4, s. 691-710.

/// Arendt H. 2008. Korzenie totalitaryzmu, tłum. D. Grinberg, M. Szawiel, tom. I i II, Wydawnictwa Akademickie i Profesjonalne.

/// Baczko B. 2016. Światła utopii, tłum. W. Dłuski, Wydawnictwo IFiS PAN.

/// Bakke M. 2010. Posthumanizm: çłtowiek w śmiecie wiekszym niž lud₹ki, [w:] Cz̨owiek wobec natury - bumanizm wobec nauk przyrodniczych, red. J. Sokolski, Neriton, s. 337-357.

/// Bauman Z. 1998. Prawodawcy i ttumacze, tłum. A. Ceynowa i J. Giebuktowski, Wydawnictwo IFiS PAN.

/// Bauman Z. 2006. Społeczeństwo w stanie oblę̇enia, tłum. J. Margański, Sic!.

/// Bauman Z. 2007. Plynne crasy. Życie w epoce niepewności, tłum. M. Żakowski, Sic!.

/// Bauman Z. 2010. Socjalizm. Utopia w driałaniu, tłum. M. Bogdan, Wyd. Krytyki Politycznej.

/// Bauman Z. 2018. Retrotopia. Jak rzqdzৃi nami pržesztość?, tłum. K. Lebek, WN PWN.

/// Baudrillard J. 1998. Ameryka, tłum. R. Lis, Sic!.

/// Baudrillard J. 2005. Symulakry i symulacja, tłum. S. Królak, Sic!.

/// Baudrillard J., Petit P. 2001. Przed końcem. Rozmawia Pbilippe Petit, tłum. R. Lis, Sic!.

/// Beck U. 2009. Społeczeństwo ryzyka: w drodze do innej nowoczesności, tłum. S. Cieśla, Scholar. 
/// Berlin I. 2004. Pokrzymione drzemo ç̧owiecz̧eństwa, tłum. M. Pietrzak-Merta, M. Tański, Prószyński i S-ka.

/// Bertman S. 1998. Hyperculture. The Human Cost of Speed, Praeger.

/// Bińczyk E. 2018. Epoka ç̨łowieka. Retoryka i marąm antropocenu, Wydawnictwo Naukowe PWN.

/// Bloch E. 1982. Rzeczywistość antycypowana, czyli jak przebiega i co osiaga myślenie utopijne, tłum. A. Czajka, „Studia Filozoficzne”, nr 7-8, s. 49-57.

/// Bloch E. 1986. The Principle of Hope, Basil Blackwell.

/// Boym S. 2001. The Future of Nostalgia, Basic Books.

/// Brzeziński D. 2015. Myślenie utopijne w teorii społecそnej Zygmunta Baumana, Wydawnictwo Naukowe Scholar.

/// Claeys G., Sargent L.T., red. 1999. The Utopia Reader, New York University Press.

/// Cross G. 2015. Consumed Nostalgia. Memory in the Age of Fast Capitalism, Columbia University Press.

/// Cyrzan H. 2004. O potrzebie utopii. Z driejón utopii stosowanej XX wieku, Wyd. Adam Marszałek.

/// Eco U. 1996. Semiologia 乏̇ycia codžiennego, tłum. J. Ugniewska, P. Salwa, Czytelnik.

/// Eger M.A., Valdez S. 2015. Neo-nationalism in Western Europe. „European Sociological Review", nr 1, s. 115-130.

/// Eriksen T.H. 2013. Etniczność i nacjonalizm. Ujecie antropologiczne, tłum. B. Gutowska-Nowak, Wydawnictwo Uniwersytetu Jagiellońskiego.

/// Featherstone M. 2007. Tocqueville's Virus: Utopia and Dystopia in Western Social and Political Thought, Routledge.

/// Featherstone M. 2009. On Critical Paranoia: Political Surrealism and Kinetic Utopia, „State of Nature”, nr 3, tekst dostępny na stronie: http://www. stateofnature.org/onCriticalParanoia.html; dostęp: 15.02.2018.

/// Fukuyama F. 2009. Koniec historii, tłum. T. Bieroń, M. Wichrowski, Znak. 
/// Gellner E. 1991. Narody i nacjonalizm, tłum. T. Hołówka, Państwowy Instytut Wydawniczy.

/// Guffey E. 2014. Crafting Yesterday's Tomorrows: Retro-Futurism, Steampunk, and the Problem of Making in the Twenty-First Century, ,The Journal of Modern Craft", nr 3, s. 249-266.

/// Grodecki M. 2016, „Święta Wojna” klasy średniej. „Industrialna kultura” kibicowania klubom piłki recrnej wobec wolnorynkowej nostalgii, „Studia Socjologiczne", nr 4, s. 305-331.

/// Hayden P., El-Ojeili Ch., red. 2009. Globalization and Utopia. Critical Essays, Palgrave Macmillan.

/// Jacobsen M.H., Tester K., red. 2012. Utopia: Social Theory and the Future, Ashgate.

/// Jacoby R. 1999. The End of Utopia: Politics and Culture in an Age of Apathy, Basic Books.

/// Jacoby R. 2005. Picture Imperfect: Utopian Thought for an Anti-Utopian Age, Columbia University Press.

/// Jacyno M. 2007. Kultura indywidualizmu, Wydawnictwo Naukowe PWN.

/// Jameson F. 2011. Archeologie przyszłości. Pragnienie zwane utopiq i inne fantazje naukowe, tłum. M. Płaza, M. Frankiewicz, A. Miszk, Wyd. Uniwersytetu Jagiellońskiego.

/// Jawłowska A. 1975. Drogi kontrkultury, PIW.

/// Kołodko G.W., Koźmiński A.K. 2017. Nowy pragmatyẓm kontra nowy nacjonalizm, Pruszyński i S-ka.

/// Levitas R. 1990. The Concept of Utopia, Philip Allan.

/// Levitas R. 2001. For Utopia: The (Limits of the) Utopian Function in Late Capitalist Society, [w: The Philosophy of Utopia, red. B. Goodwin, Routledge, s. $25-43$.

/// Levitas R. 2003. Introduction: the elusive idea of utopia, „History of the Humans Sciences", nr 1, s. 1-10.

/// Levitas R. 2013. Utopia as Method. The Imaginary Reconstitution of Society, Palgrave MacMillan. 
/// Lyotard J.-F. 1997. Kondycja ponowoczesna: raport o stanie wiedzy, tłum. M. Kowalska i J. Migasiński, Aletheia.

/// Molenda M. 2016. Nostalgia za wiekem pary, „Creatio Fantastica”, nr 1(52), s. $1-16$.

/// Moylan T., Baccolini R., red. 2007. Utopia, Method, Vision. The Use Value of Social Dreaming, Lang.

/// Nietzsche F. 2012. Narodziny tragedii; Niewczesne rozważania, tłum. P. Pieniążek, M. Łukasiewicz, Wydawnictwo Officyna.

/// Paleczny T. 1997. Kontestacja. Formy buntu we wspólczesnym spoleczeństwie, Nomos.

/// Połap M. 2016. Milenialsem jestem, „Reflektor”, nr 3, s. 7-13.

/// Popper K. 1999. Droga do wiedzy. Domysty i refutacje, tłum. S. Amsterdamski, PWN.

/// Popper K. 2006. Społeczeństwo otwarte i jego wrogowie, tłum. H. Krehelska, W. Jedlicki, t. 1 i 2 , PWN.

/// Rüsen J., Fehr M. i Rieger T.W., red. 2005. Thinking Utopia. Steps into Other Worlds, Berghahn Books.

/// Sargent L.T. 1994. The Three Faces of Utopianism Revisited, „Utopian Studies", nr 1, s. 1-37.

/// Sargent L.T. 2005. A Necessity of Utopian Thinking: A Cross-Ntional Perspective, [w:] Thinking Utopia. Steps into Other Worlds, red. J. Rüsen, M. Fehr, T.W. Rieger, Berghahn Books, s. 1-14.

/// Sargent L.T. 2006. In defense of Utopia, „Diogenes”, nr 1, s. 11-17.

/// Sargent L.T. 2010. Utopianism. A Very Short Introduction, Oxford University Press.

/// Saryusz-Wolska M., Traba R., red. 2014. Modi memorandi. Leksykon kultury pamieci, Wydawnictwo Naukowe Scholar.

/// Skrzypczak P. 2010. Derrida $i$ Wittgenstein. O iterowalności i kierowaniu sie reguta, „Diametros”, nr 24, s. 107-124.

/// Smolik B. 2015. Wspótçesny nacjonaliẓm w Europie - próba charakterystyki wybranych aspektów, „Wrocławskie Studia Politologiczne”, nr 19, s. 98-112. 
/// Szacki J. 2000. Spotkania z utopia, Sic!.

/// Talmon J. 1952. The Origins of Totalitarian Democracy, Secker \& Warburg.

/// Turner B.1987. A Note on Nostalgia, „Theory, Culture \& Society”, nr 4(1), s. $147-156$.

/// Tyszka K. 2009. Cそy ґ்yjemy w opoce „śmierci utopï”?, „Kultura i Społeczeństwo", nr 1, s. 83-103.

\section{/// Abstrakt}

W niniejszym artykule koncentruję się na przemianach mających miejsce w myśli utopijnej w obecnym stuleciu. Dowodzę, że przekonanie o zmierzchu utopii - szeroko rozpowszechnione zwłaszcza pod koniec XX wieku - można uznać za słuszne tylko w przypadku jednej z jej form. Owa charakteryzuje się dążeniem do stworzenia niezmiennego, doskonałego, a jednocześnie też uniwersalnego ładu, w czym fundamentalną rolę odgrywać mają mechanizmy dyscyplinarne. W opozycji do takich wyobrażeń rozwijają się dziś dynamicznie inne wizje przyszłości, których trzy - w moim przekonaniu najistotniejsze - typy przedstawiam w niniejszym artykule. Jednym z nich są koncepcje „ikonoklastyczne”, których twórcy odstępują od kreślenia szczegółowych planów przyszłego porządku na rzecz transcendowania istniejącej rzeczywistości i wskazywania głównych kierunków potrzebnych zmian. Kolejną stanowią utopie „dionizyjskie”, zorientowane na potrzeby poszczególnych jednostek, a jednocześnie charakteryzujące się permanentną zmiennościa. Trzecia grupa to koncepty „retrospektywne” - stanowiące odzwierciedlenie ,zwrotu nostalgicznego” - w których przypadku punktem odniesienia dla kreślenia wizji lepszej przyszłości są czasy minione. W artykule dowodzę, że myśl utopijna nie tylko nie ulega dziś upadkowi, ale można wręcz zaobserwować jej renesans, czemu towarzyszy daleko posunięta ewolucja.

Słowa kluczowe:

utopia, projekt, transcendowanie, kultura indywidualizmu, zwrot nostalgiczny 


\section{/// Abstract}

In this paper I analyse the transformations that have taken place within utopian thinking since the beginning of the century. I claim that the idea of "the death of utopia" - which was widely discussed at the end of the $20^{\text {th }}$ century - may be considered right in one of its forms only. This particular one is characterized by a will to create a model of an unchangeable, perfect, universal world where the disciplinary mechanism would play a crucial role. In contrast to such ideas some other visions of the future have been developing dynamically in recent years. Three types of such visions - as far as I am concerned the most important ones - are presented in this paper. The first group are iconoclastic utopias that authors withdraw from delineating detailed plans for the future in favor of both emphasising a need to transcend the existing reality and indicating the main directions of the changes. The second group are the "Dyonisian" utopias that are oriented towards the individual needs and are characterized by permanent changeability. The third group are retrospective utopias in which the historical events are the point of reference for creating the visions of better future. I argue that utopian thinking is not only developing these days, but that we are witnessing its reneissance and far-reaching evolution.

Keywords:

blueprint utopia, iconoclastic utopia, Apollonian and Dionysian, nostalgia, retrotopia

/// Dariusz Brzeziński - doktor nauk społecznych, adiunkt w Zakładzie Socjologii Teoretycznej IFiS PAN. Jego zainteresowania naukowe obejmują głównie współczesną myśl społeczną, a także socjologię, antropologię i teorię kultury. W tych obszarach prowadzi również wykłady i zajęcia dydaktyczne na Uniwersytecie Jagiellońskim. Ostatnio opublikował: Twórczość Zygmunta Baumana w kontekśscie wspótczesnych teorii kultury (2017).

Email: dariusz.brzezinski@ifispan.waw.pl 